\title{
PENERAPAN AKUNTANSI DALAM ADMINISTRASI BISNIS PERGUDANGAN (STUDY KASUS: PENYELESAIAN SELISIH PERSEDIAAN )
}

\author{
Muhammad Sapruwan \\ 1) Universitas Pelita Bangsa, Jl. Inpeksi Kalimalang Cikarang Kabupaten Bekasi 17530, Jawa Barat \\ msapruwan@yahoo.com
}

\begin{abstract}
ABSTRAK
Penelitian ini berkaitan dengan permaslahan persediaan barang di gudang. Tujuan penelitian ini adalah mengetahui apa saja selisih persediaan, mengetahui, apa saja penyebab terjadinya selisih persediaan, Mengetahui apa saja dampak selisih persediaan, tindakan bagaimana perbaikan selisih persediaan dari sudut akuntansi. Metode penelitian yang digunakan adalah diskritif kualitatif dan kuantitatif, dengan metode pencatatan akuntansi Phisical Inventory Sistem Hasil temuan penelitian ini adalah langkah-langkah tindakan akuntansi yang harus dilakukan untuk menyelesaikan permasalahan selisih persediaan barang di gudang. Implikasi dari temuan ini adalah memberikan informasi persediaan yang akurat di laporan keuangan, memberikan pengetahuan dan pembelajaran bagi pelaku bisnis pergudangan, dan akademisi tentang bagaimana penyelesaian selisih persediaan barang di gudang dengan pendekatan akuntansi.
\end{abstract}

Kata Kunci : Akuntansi, Pergudangan, dan Persediaan

\section{ABSTRACT}

This research is related to the problem of inventory in the warehouse. The purpose of this research is find out what is the difference in inventory, find out what are the causes of inventory discrepancies, Knowing what the effects of inventory differences are, actions on how to correct the difference in inventory from an accounting point of view. The research method used is qualitative and quantitative descriptions, by recording method accounting Physical Inventory System. The findings of this study are accounting action steps which must be done to solve the problem of differences in inventory in the warehouse. The implications of this finding are provide accurate inventory information in financial statements, provide knowledge and learning for warehousing businesses, and academics about how to settle the difference in inventory in the warehouse with an accounting approach.

Keywords : Accounting, Warehouse, and Inventory

\section{PENDAHULUAN}

Setiap orang sebelum menjalankan tugasnya diperusahaan pasti ingin mengetahui terlebih dahulu kondisi perusahaan didalamnya. Salah satu asset yang penting untuk diketahui lebih lanjut adalah inventarisasi asset persediaan yang tersimpan digudang. Hal ini penting untuk diketahui berapa jumlah nilai asset persediaan yang sebenarnya. Ada peribahasa mengatakan " tidak makan nangkanya kena getahnya “. Ada permasalahan persediaan dimasa lalu akan tetapi menjadi pertanggung jawaban kita saat ini. Hal ini terjadi karena kelalain kita dalam menerima tanggung jawab asset persediaan yang tersimpan di gudang dengan tidak melakukan stock op-name sebelumnya.

Gudang adalah suatu tempat penyimpanan berbagai macam jenis barang dalam jumlah yang besar maupun kecil, sebelum barang tersebut di gunakan dalam jangka waktu tertentu, untuk tujuan tertentu. Gudang memiliki peranan yang sangat penting dalam menunjang kegiatan operasional suatu perusahaan yakni penerimaan,penyimpanan dan pengeluaran barang. Banyak pihak yang tidak terlalu memperhatikan keberadaanya sehingga baik sengaja maupun tidak sengaja dalam menjalankan aktivitasnya menimbulkan terjadinya selisih persediaan. Persediaan di gudang bermacam-macam 
bentuk phisiknya mulai dari bahan baku, barang dalam proses, barang jadi, dan bahan penolong atau bahan pembantu lainnya..

Inventarisasi asset persediaan pada umumnya dilakukan dengan cara stock opname. Hendaknya Stock opname dilakukan secara menyeluruh " Total Jendral " agar dikemudian hari diketahui sampai batas mana pertanggung-jawabannnya. Stock opname merupakan kegiatan mengontrol antara administrasi dan fisik barang. Dengan diadakanya stock opname maka akan diketahui apakah laporan stock benar atau tidak. Setiap terjadi stock op-name sering ditemukan permasalahan dimana data stock gudang yang dilaporkan tidak mencerminkan kondisi fisik yang sebenarnya. Contoh temuan permasalahan stock opname yang didapatkan sebagai berikut : adanya persediaan barang yang tidak memiliki daftar harga barang, adanya phisik persediaan yang lebih kecil jumlahnya dari catatan gudang, adanya phisik persediaan yang lebih besar jumlahnya dari catatan gudang, adanya phisik barang yang tercatat gudang sedangkan fisiknya tidak ada, Tidak tertib administrasi gudang seperti Bon Permitaan Barang Menyusul, Tidak up to date dalam input data baik penerimaan barang maupun pengeluaran barang, tidak akurat dalam pengisian Bon Permintaan Barang, dan sebagainya.

Permasalahan tersebut disebabkan adanya beberapa factor seperti : seringnya turn over petugas gudang, Pengawasan manajemen tidak berjalan sebagaimana mestinya, kebijakan manajemen pergudangan yang kurang tepat. Tidak pernah dilakukan koreksi kesalahan, dan sebagainya. Mengingat banyak factor penyebab terjadinya selisih persediaan barang di pergudangan , maka penulis tertarik untuk melakukan kajian ilmiah yakni : Apa saja selisih persediaan di gudang, apa saja penyebab terjadinya selisih persediaan di gudang, apa saja dampak selisih persediaan digudang, dan bagaimana perbaikan selisih persediaan di gudang dari sudut akuntansi, sedangkan sanksi dan lainnya, tidak dibahas disini. Untuk itu penulis tertarik mengambil judul Penyelesaian Selisih Persediaan Barang Dengan Pendekatan Akuntansi Di Gudang

\section{KAJIAN PUSTAKA}

\section{Akuntansi}

Menurut Financial Accounting Standards Board (FASB) (2017) merupakan kegiatan jasa yang berfungsi menyediakan suatu informasi kuantitatif yang kemudian digunakan untuk pengambilan keputusan ekonomi. Menurut Sheila Alifanny (2020) Sistem akuntansi persediaan bahan penolong yang baik sangat berdampak dalam memperbaiki pengendalian internal karena jaringan prosedur, dokumen, catatan dan fungsi akan mempengaruhi proses berjalannya suatu pengandalian internal yang ada, dengan adanya kelengkapan dokumen, catatan, serta fungsi yang terkait pesediaan bahan penolong akanmempermudah jalannya pengendalian internal dan memperbaiki tingkat keandalan informasi akuntansi.

Sumarsan (2017:1) adalah suatu seni untuk mengumpulkan, mengidentifikasi, mengklasifikasikan, mencatat transaksi, serta kejadian yang berhubungan dengan keuangan, sehingga dapat menghasilkan informasi keuangan atau suatu laporan keuangan yang dapat digunakan oleh pihak-pihak yang berkepentingan. Catur Sasongko (2016), Akuntansi proses/aktivitas yang menganalisis, mencatat, mengklasifikasikan, mengikhtisarkan, melaporkan, dan menginterprestasikan informasi keuangan untuk kepentingan para penggunanya. Dengan demikian secara teknis dapat dirumuskan, akuntansi meliputi tahapan : Bukti Transaksi - Jurnal (jurnal transaksi, Jurnal Penyesuaian, Jurnal Penutup, Jurnal Balik) - Buku Besar - Laporan Keuangan ( L/R, dan Neraca ). Dalam kajian ini penulis berfokus tentang bagaimana penerapan akuntansi bilamana dipergunakan dalam administrasi bisnis pergudangan terutama untuk transaksi koreksi selisih persediaan.

\section{Persediaan}

Menurut Handoko. (2015), Persediaan (inventory) adalah suatu istilah umum yang menunjukan segala sesuatu atau sumber daya-sumber daya organisasi yang disimpan dalam antisipasinya terhadap pemenuhan permintaan. Kieso, D. E., Weygandt, J. J., \& Warfield, T. D. (2015), Persediaan (Inventory) adalah pos-pos aktiva yang dimiliki perusahaan untuk dijual dalam operasi bisnis normal atau barang yang akan digunakan atau dikonsumsi dalam memproduksi barang yang akan dijual. Menurut Ikatan Akuntan Indonesia dalam Standar Akuntansi Keuangan (2018) Istilah persediaan sendiri didefinisikan sebagai aset yang: dimiliki dan untuk dijual dalam kegiatan 
usaha biasa, dalam proses produksi untuk dijual, dalam bentuk bahan atau perlengkapan (supplies) untuk digunakan dalam proses produksi atau pemberian jasa. Dalam kajian ini penulis berfokus pada akurasi laporan persediaan, sehingga kesalahan-kesalahan seperti selisih lebih stock atau sebaliknya dapat segera diperbaiki.

\section{Gudang}

Menurut Olivia Audrey dkk (2019) Gudangadalah tempat yang dibebani tugas untuk menyimpan barang yang akan dipergunakan dalam produksi, sampai barang tersebut diminta sesuai jadwal produksi.Menurut Zaroni. 2017, Gudang merupakan komponen penting dari rantai pasokan modern. Rantai pasokan melibatkan kegiatan dalam berbagai tahap: sourcing, produksi, dan distribusi barang, dari penanganan bahan baku dan barang dalam proses hingga produk jadi. Gudangdapat digambarkan sebagai bagian dari suatu sistem logistik sebuah perusahaan yang berfungsi untuk menyimpan produk dan menyediakan informasi mengenai status serta kondisi material/persediaan yang disimpan di gudang, sehingga informasi tersebut selalu up-to-date dan mudah diakses oleh siapa pun yang berkepentingan. Menurut Martono (2015) fungsi gudang :1. Menyimpan barang untuk sementara waktu sambil menunggu giliran untuk diproses. 2. Memantau pergerakan dan status barang. 3. Meminimumkan biaya pergerakan barang, peralatan, dan karyawan. 4. Menyediakan media komunikasi dengan konsumen mengenai barang. 5. Titik penyeimbang aliran inventory dan barang.

Aktivitas gudang di PT. KMB meliputi penerimaan, penyimpanan, dan pengeluaran barang. Dalam kajian ini penulis berfakus tindak lanjut selisih persediaan yang ditimbulkan sehubungan dengan adanya aktivitas penerimaan, dan pengeluaran persediaan barang di gudang dari hasil stock opname.

\section{METODE PENELTIAN}

Tahapan yang akan dilakukan yaitu pengumpulan data dan informasi yang berkaitan dengan aktivitas persediaan barang di pergudangan, dengan cara melakukan studi pustaka, kemudian diolah, disusun menjadi laporan. Penelitian ini menggunakan pendekatan Diskritif kuantitatif yakni mendiskripsikan sesuatu hal penyebab masalah, dan menyelesaikan langsung permasalahan secara matematik (hitung-hitungan) dan administrasi pembukuan (akuntansi). Metode analisis akuntansi yang digunakan adalah metode pencatatan Phisical Inventory Sistem yakni pencatatan selisih persediaan hanya dilakukan pada akhir periode akuntansi melalui ayat jurnal penyesuaian.

\section{HASIL DAN PEMBAHASAN \\ Diskripsi Data}

Data informassi persedian gudang diperoleh dari salah satu perusahaan yang berinisial PT KMB. Salah satu perusahaan yang bergerak dibidang industri perkebunan dan pabrik kelapa sawit yang berlokasi di sampit Kalimantan Tengah. Dari hasil stock opname didapatlah hasil : Ada barang yang fisiknya lebih banyak dari jumlah dilaporan stock, Ada barang yang fisiknya lebih sedikit dari jumlah dilaporan stock. Dan banyak lagi temuan permasalahan dari stock op name. Data hasil stock opname tidak dicantumkan secara keseluruhan, oleh karena kuantitas datanya yang banyak, serta menjaga kerahasiaan perusahaan. Penulis akan sajikan permasalahan data dari hasil stock opname secara sampel seperti pada Tabel 1.

Tabel 1. Hasil Stock Opname

\begin{tabular}{|c|c|c|c|c|c|}
\hline NOMOR ITEM & JENIS BARANG & SATUAN & $\begin{array}{l}\text { STOK } \\
\text { AKHIR }\end{array}$ & $\begin{array}{l}\text { HASIL } \\
\text { STOCK } \\
\text { OPNAME }\end{array}$ & SELISIH \\
\hline 1.01 .10 .07 .05 .04 .090 & Lock Ring $150 / 12.5$ & pcs & 12 & 11 & -1 \\
\hline 1.01 .10 .07 .05 .04 .094 & $\begin{array}{l}\text { Lock Ring FRM 100,9,5 } \\
\text { FAG }\end{array}$ & bh & 8 & 9 & 1 \\
\hline 1.01 .10 .07 .05 .04 .098 & $\begin{array}{l}\text { Lock Rimg Plummer SNV } \\
200 \text { (FRB } 135 / 200 \text { SKF) }\end{array}$ & pes & 4 & 3 & -1 \\
\hline 1.01 .10 .07 .05 .04 .099 & Locking Washer KM 22 & $\mathrm{bh}$ & 3 & 4 & 1 \\
\hline 1.01 .10 .07 .05 .04 .110 & Nepel Smm & $\mathrm{bh}$ & 23 & 21 & -2 \\
\hline 1.01 .10 .07 .05 .04 .118 & Oil Seal $25 \times 62 \times 10$ & bh & 5 & 4 & -1 \\
\hline 1.01 .10 .07 .05 .04 .122 & Oil Seal $50 \times 65 \times 8$ & $\mathrm{bh}$ & 4 & 3 & -1 \\
\hline 1.01 .10 .07 .05 .04 .126 & Oil Seal $30 \times 50 \times 10$ & $\mathrm{bh}$ & 20 & 19 & -1 \\
\hline
\end{tabular}

Sumber : Data olahan, 2021 
terjadi karena :

Melalui interview dan observasi data, permasalahan selisih persediaan tersebut sepertinya

a. Selisih persediaan barang terjadi karena kurangnya ketelitian petugas gudang dalam pencatatan barang. Misalnya : Sudah dibuatkan Bukti Keluar Barang akan tetapi fisik barang tidak jadi dikeluarkan. Sehingga terjadi selisih lebih. Kemudian, ada pengambilam barang tanpa Bon Permintaan dengan alasan mendesak Bon Permintaan menyusul. Berjalannya waktu terjadi selisih kurang fisik persediaan dari laporan stock.

b. Lemahnya pengetahuan petugas gudang terhadap administrasi gudang, misalnya : belum tahu cara menyelesaikan permasalahan silsih persediaan.

c. Pengawasan tidak berjalan sebagaimana mestinya, tidak ada file bukti adanya stock opname.

d. Seringnya turn over petugas gudang termasuk staff pimpinan gudang yang tidak diikuti dengan serah terima ( file serah terima tidak ditemukan),

e. Belum pernah di evaluasi ( koreksi administrasi laporan/catatan gudang) sejak PT.KMB mulai di bangun.

Dampak Laporan stock yang salah yang diberikan kepada manajemen selama ini adalah informasi keuangan yang menyesatkan. Sehingga pengambilan keputusan oleh manajemen bisa salah, memberikan dampak pelayanan gudang terhadap pengguna menjadi buruk dan berpengaruh terhadap opersional perusahaan, asset yang hilang (pisik lebih kecil dari catatan), dimana tidak diketahui apakah terjadi karena adanya penyimpangan petugas gudang atau karena kesalahan manajemen pengelolaan persediaan, dan tidak tahu siapa yang musti bertanggung-jawab

\section{Pembahasan}

Merujuk temuan hasil stock opname seperti yang penulis uraikan dalam diskripsi data diatas, maka upaya perbaikan yang akan dilakukan melalui tahapan sebagai berikut :

\section{Gambar 1. Tahapan Perbaikan Selisih Persedian}

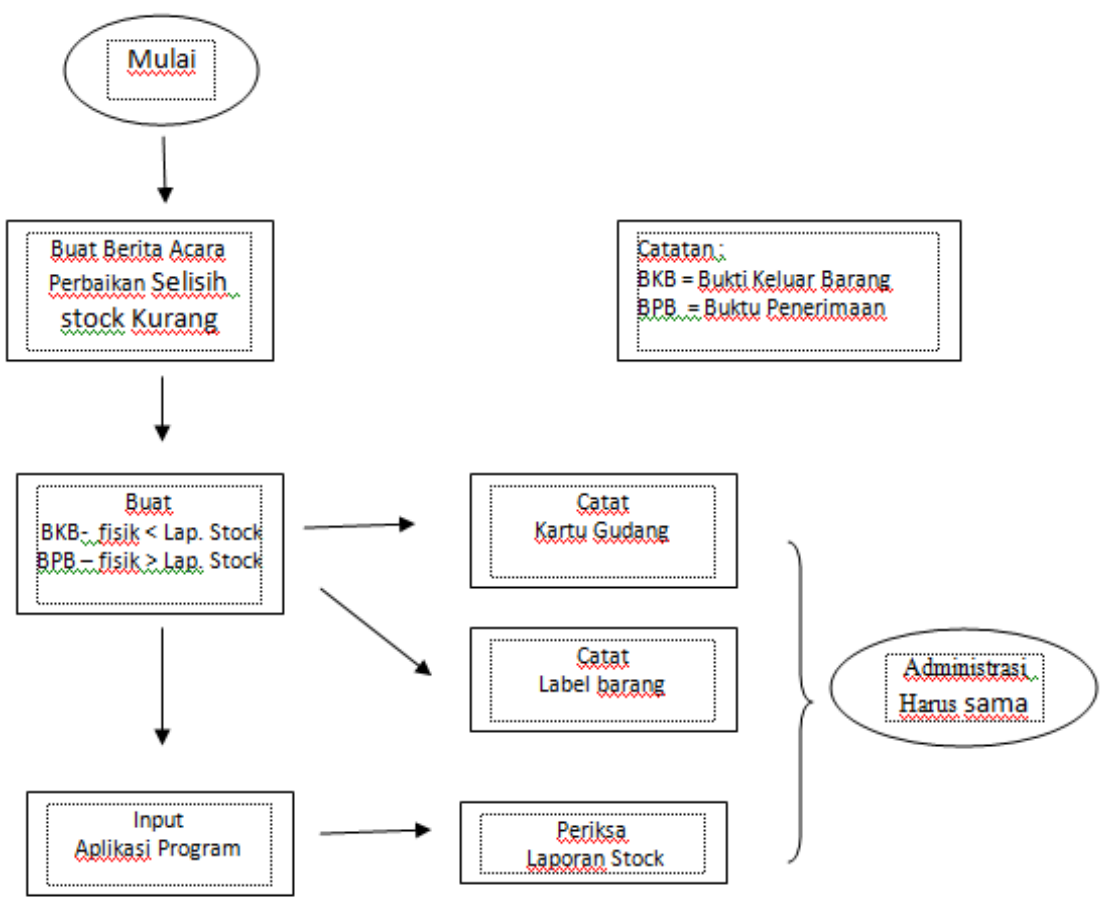

Sumber : Data olahan, 2021

Penjelasan :

1. Mulai,

2. Pembuatan Berita Acara Perbaikan Selisih Persediaan, mengisi semua phisik yang selisih baik selisih lebih maupun selisih kurang. dan dimintakan persetujuan pimpinan terkait. Gambar 2 (BAP Perbaikan Selisih Persediaan); 
PT. KMB

\section{Gambar 2. BAP Perbaikan Selisih Persediaan}

BERITA ACARA SELISIH BARANG

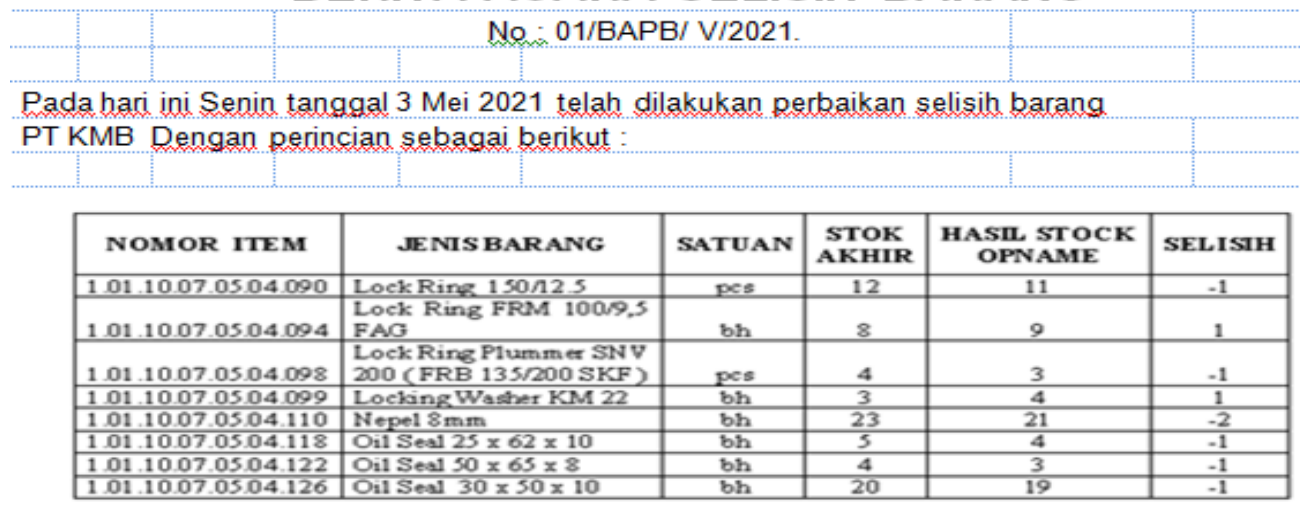

Demikian kami scmpaikin, Atas perhatiarnya kami ucopakan terima kash

Disetujui,

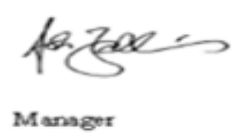

Diperiksa

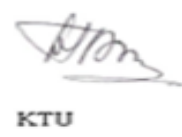

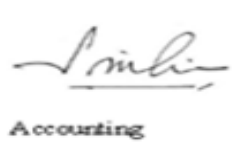

Dibuat,

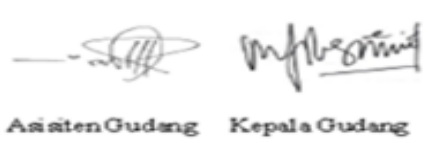

Sumber : Data Olahan, 2021

3. Pembuatan Bon Permintaan Barang, dimintakan persetujuan pimpinan terkait (Administrasi ini bisa dilewati Bilamana BAP selisih perbaikan sudah dianggap bukti yang cukup);

4. Jika Phisik persediaan lebih kecil dari laporan stock, maka membuat Bukti Keluar Barang (BKB). mengisi jumlah barang yang akan dikeluarkan dari laporan stock sesuai dengan selisih kurang yang ditemukan. Selanjutnya dimintakan persetujuan pimpinan terkait. Bukti Keluar Barang inilah sesungguhnya jurnal koreksi dari sudut pandang akuntansi, hanya saja terjadinya transaki koreksi atas fisik yang kurang dari jumlah dilaporan stock di bagian gudang bukan dibagian akunting. Dari sudut akunting BKB inilah bukti transaksi pemakaian persediaan yang nantinya akan diinput ke program stock dan transaksi yang sudah terinput tersebut nantinya akan ditransfer ke Geneal Ledger ( GL). Disinilah keterkaitannya dengan akunting. Subtansi Bukti Keluar Barang adalah jurnal koreksi sebagai berikut:

Gambar 3

Bukti Keluar Barang

\begin{tabular}{|c|c|c|c|c|}
\hline PT. KMB & & & Nemor & $\begin{array}{c}001 / \\
\text { CU/N/2021 }\end{array}$ \\
\hline & BUKTI KELUAR & BARANG & Tanggal & 3 Mei 2021. \\
\hline
\end{tabular}

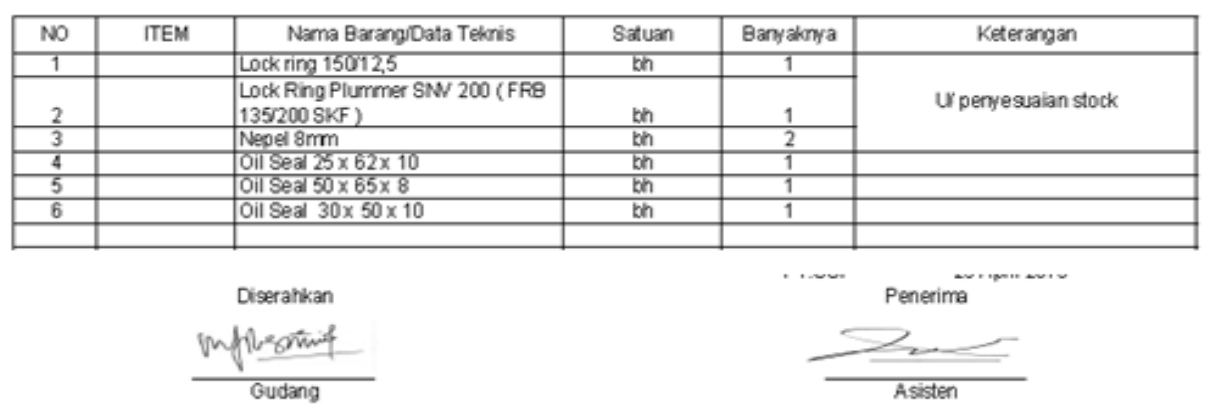

Sumber : Data Olahan, 2021 
5. Jika phisik lebih besar dari laporan stock, maka berdasarkan BA Selisih Persediaan membuat Bukti Penerimaan Barang ( BPB). mengisi jumlah barang yang diterima sesuai dengan selisih lebih yang ditemukan.

Selanjutnya dimintakan persetujuan pimpinan terkait. BPB inilah sesungguhnya jurnal koreksi dari sudut pandang akuntansi, hanya saja terjadinya transaki koreksi atas fisik yang lebih dari jumlah dilaporan stock di bagian gudang bukan dibagian akunting. Dari sudut akunting BPB inilah bukti transaksi penerimaan persediaan yang nantinya akan diinput ke program stock, dan BPB yang sudah terinput tersebut nantinya akan ditransfer ke Geneal Ledger ( GL). Disinilah keterkaitannya dengan akunting. Subtansi BPB adalah jurnal koreksi sebagai berikut:

$$
\begin{aligned}
& \text { Persediaan A } \\
& \text { Biaya selisih Persediaan A............xxxx }
\end{aligned}
$$

Atau

$$
\text { Persediaan A } \quad \ldots . x x x x
$$

BDP - selisih Persediaan A...........xxxx

(catatan :Jurnal koreksi disesuaikan dengan company bisnis)

Input harga persediaan bisa disesuaikan dengan PO (Purchase Order) bilamana masih ada filenya, harga rata-rata di laporan stock, harga PO terakhir persediaan sejenis, atau harga pasaran terakhir, tergantung kebijakan manajemen melihat harga yang paling wajar yang masih bisa diterima. Akuntansi yang digunakan diatas adalah Metode Phisical Inventory Sistem yakni pencatatan selisih persediaan hanya dilakukan pada akhir periode akuntansi melalui ayat jurnal penyesuaian dalam hal ini berdasarkan laporan hasil stock opname.

Bilamana sewaktu-waktu petugas gudang mengetahui adanya selisih phisik lebih dan sudah memahami bagaimana melakukan jurnal koreksi, maka dapat digunakan Metode Perpectual (Continual Inventory Sistem) yakni pencatatan selisih persediaan dilakukan setiap terjadi selisih transaksi yang mempengaruhi persediaan dengan mengacu pada perbaikan diatas.

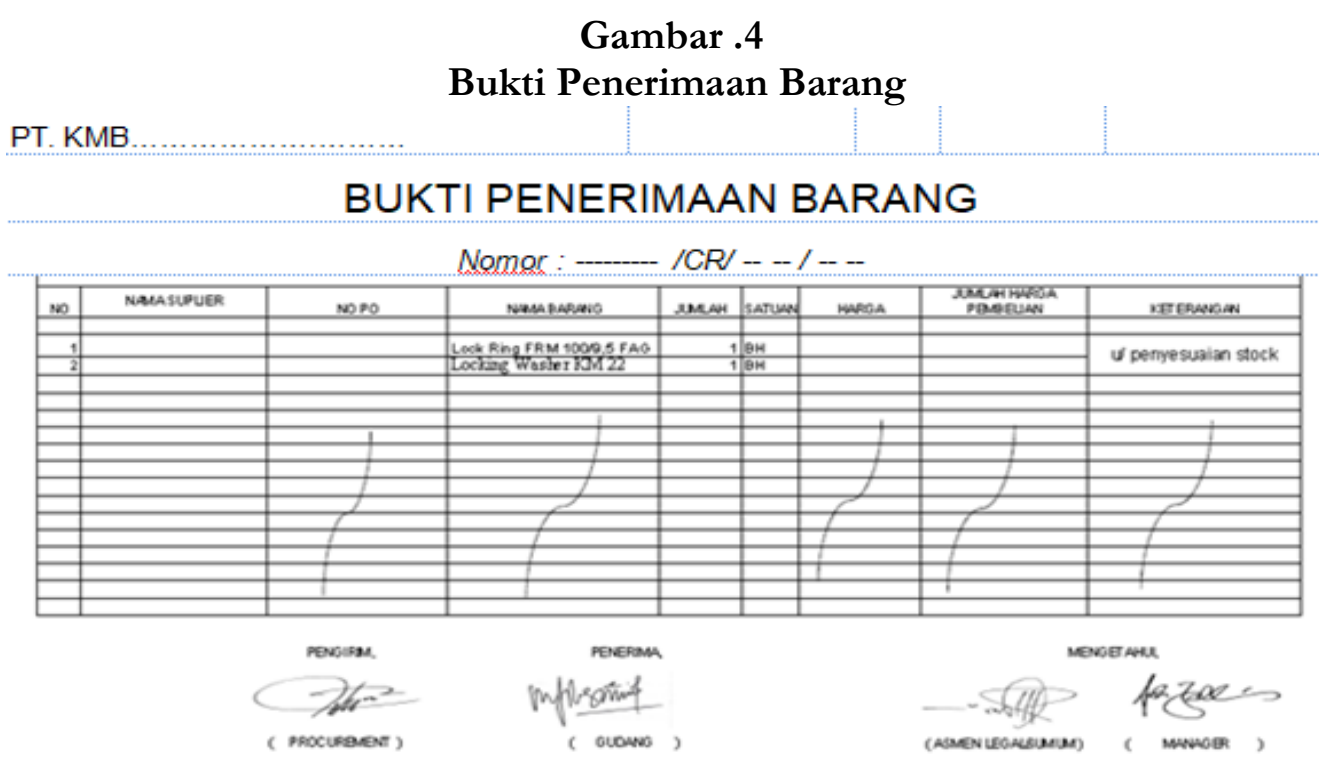

Sumber : Data Olahan, 2021

6. Input BKB Dan BPB ke aplikasi program stock (Data Proses Input dalam kajian ini tidak dapat ditampilkan berhubung data stock sudah diprotek oleh perusahaan ).

7. Berdasarkan BKB dan BPB, dicatatt ke Kartu Gudang dan ke Label Barang. Bentuk Kartu Gudang dan Label Barang pada umumnya sama.namun Kartu Gudang ukurannya biasanya lebih Besar dibandingkan Label Barang. Baik Kartu Gudang maupun Label Barang ini tidak ada kaitannya dengan proses akuntansi, namun perannya sangat besar karena dapat 
digunakan untuk alat control petugas gudang terhadap persediaan sehigga selisih persediaan dapat diminimalkan. Kartu Gudang biasanya berada di meja petugas gudang, sedang Label Barang biasanya menempel pada rak-rak tempat penyimpanan persediaan sesuai kelompoknya atau jenisnya. Berikut Gambar 5 adalah contoh form bentuk Kartu Gudang / Label Barang.

\section{Gambar.5 Kartu Stock}

\section{PT . KMB 宊}

KARTU GUDANG

\begin{tabular}{|c|c|c|c|c|c|}
\hline \multicolumn{4}{|c|}{ NAMA BARANG :Lock ring 150/12.5 } & \multicolumn{2}{|c|}{1.01 .10 .07 .05 .04 .090} \\
\hline Tgl & Nomor Bukti & Uraian & Masuk & Keluar & Sisa \\
\hline $1 / 1 / 15$ & & Stock Awal & & & 12 \\
\hline $23 / 4 / 19$ & & w' peryesuaian stock & & 1 & 11 \\
\hline & & & & & \\
\hline & & & & & \\
\hline & & & & & \\
\hline & & & & & \\
\hline & & & & & \\
\hline & & & & & \\
\hline
\end{tabular}

Sumber : Data Olahan, 2021

8. Evaluasi hasil perbaikan setelah jurnal koreksi dengan memeriksa hasil akhir Laporan stock, Kartu Gudang, dan Label Barang, mustinnya hasil akhirnnya sama ( angka-angka dalam dokumen ) karena sumber input sama yakni BKB. Selanjutnya dibandingkan dengan jumlah phisik persediaan yang tersedia. Pada TABEL IV.2. adalah evaluasi hasil akhir dari upaya perbaikan jurnal koreksi atas selisih persediaan fisik lebih kecil dibandingkan laporan stock. Pada TABEL IV.3. adalah evaluasi hasil akhir dari upaya perbaikan jurnal koreksi atas selisih persediaan fisik lebih besar dibandingkan laporan stock.

Tabel 2:

Perbandingan fisik Persediaan < laporan stock.

\begin{tabular}{|c|c|c|c|c|}
\hline Jenis Barang & Laporan Stock & Kartu Stock & Fisik Barang & Selisih \\
\hline Lock Ring $150 / 12.5$ & 12 & 12 & 11 & -1 \\
\hline $\begin{array}{l}\text { Lock Ring Plummer SNV } \\
200\end{array}$ & 4 & 4 & 3 & -1 \\
\hline Nepel 8mm & 23 & 23 & 21 & -2 \\
\hline Oil Seal $25 \times 62 \times 10$ & 5 & 5 & 4 & -1 \\
\hline Oil Seal $50 \times 65 \times 8$ & 4 & 4 & 3 & -1 \\
\hline Oil Seal $30 \times 50 \times 10$ & 20 & 20 & 19 & -1 \\
\hline \multicolumn{5}{|l|}{ setelah koreksi } \\
\hline Jenis Barang & Laporan Stock & Kartu Stock & Fisik Barang & Selisih \\
\hline Lock Ring $150 / 12.5$ & 11 & 11 & 11 & 0 \\
\hline $\begin{array}{l}\text { Lock Ring Plummer SNV } \\
200\end{array}$ & 3 & 3 & 3 & 0 \\
\hline Nepel 8mm & 21 & 21 & 21 & 0 \\
\hline Oil Seal $25 \times 62 \times 10$ & 4 & 4 & 4 & 0 \\
\hline Oil Seal $50 \times 65 \times 8$ & 3 & 3 & 3 & 0 \\
\hline Oil Seal $30 \times 50 \times 10$ & 19 & 19 & 19 & 0 \\
\hline
\end{tabular}

Sumber : Data Olahan, 2021 
Tabel 3:

Perbandingan fisik Persediaan < laporan stock

\begin{tabular}{|c|c|c|c|c|}
\hline Jenis barang & $\begin{array}{l}\text { laporan } \\
\text { stock }\end{array}$ & kartu stock & fisik barang & Selisih \\
\hline $\begin{array}{l}\text { lock ring FRM } \\
\text { lOO/Q,5 FAG }\end{array}$ & 8 & 8 & 9 & 1 \\
\hline $\begin{array}{l}\text { Locking Washer } \\
\text { KM } 22\end{array}$ & 3 & 3 & 4 & 1 \\
\hline \multicolumn{5}{|l|}{ setelah dikoreksi } \\
\hline Jenis barang & $\begin{array}{l}\text { laporan } \\
\text { stock }\end{array}$ & kartu stock & fisik barang & Selisih \\
\hline $\begin{array}{l}\text { lock ring FRM } \\
10 O / 9,5 \mathrm{FAG}\end{array}$ & 9 & 9 & 9 & o \\
\hline $\begin{array}{l}\text { Locking Washer } \\
\text { KM } 22\end{array}$ & 3 & 3 & 3 & o \\
\hline
\end{tabular}

Sumber : Data Olahan, 2021

\section{Implikasi}

Dengan penerapan akuntansi melalui jurnal koreksi tersebut maka persediaan dalam laporan stock menjadi akurat, baik dokumen maupun fisik persediaan, sehingga informasi laporan keuangan sebagai dasar penngambilan keputusan manajemen PT. KMB tidak menyesatkan. Petugas gudang dapat memberikan pelayanan yang maksimal dalam menunjang kelancaran operasional produksi perusahaan. Memberikan pengetahuan dan pembelajaran bagi para pelaku bisnis lapangan, serta dunia akademik tentang bagaimana penerapan akuntansi melalui jurnal koreksi selisih persedian pada administrasi bisnis pergudangan.

\section{KESIMPULAN}

Dari hasil dan pembahasan yang telah diuraikan dalam bab sebelumnya, maka dapat disimpulkan sebagai berikut :

1. Selisih persediaan di gudang dari hasil temuan stock op-name adalah adanya selisih fisik persediaan lebih kecil dibandingkan laporan stock, dan selisih fisik persediaan lebih besar dibandingkan laporan stock.

2. Selisih persediaan di gudang disebabkan antara lain : tingginya turn over petugas gudang \& staff pimpinan gudang, kurangnya ketelitian petugas gudang dalam pencatatan barang. Lemahnya pengetahuan administrasi gudang, serta belum tahu cara menyelesaikan selisih persediaan, pengawasan tidak berjalan sebagaimana mestinya, tidak ada file bukti adanya stock opname., belum pernah di evaluasi ( koreksi administrasi laporan/catatan gudang) sejak PT.KMB mulai di bangun.

3. Dampak selisih persediaan digudang adalah informasi keuangan yang menyesatkan, sehingga pengambilan keputusan oleh manajemen bisa salah. Pelayanan gudang terhadap pengguna menjadi buruk dan berpengaruh terhadap opersional perusahaan. Aset yang hilang dimana tidak diketahui apakah terjadi karena adanya penyimpangan atau tidak, serta tidak tahu siapa yang musti bertanggung-jawab.

4. Tindakan perbaikan selisih persediaan di gudang dari sudut akuntansi melputi : a. Pembuatan BAP selisih persediaan dengan persetujuan pimpinan terkait. b. Pembuatan Bon Permintaan Barang, namun bilamana BAP selisih perbaikan dianggap bukti yang cukup, maka Bon Permintaan Barang bisa dilewatkan. c. Bilamana selisih phisik persediaan lebih kecil dibandingkan laporan stock maka diperlukan jurnal koreksi melalui Pembuatan Bukti Keluar Barang dengan persetujuan pimpinan terkait. d. Bilamana selisih phisik persediaan lebih besar dibandingkan laporan stock maka diperlukan jurnal koreksi melalui Pembuatan Bukti Penerimaan Barang dengan persetujuan pimpinan terkait. e. Menginput BKB dan BPB ke program aplikasi stock. $f$. Mencatat BKB dan BPB ke Kartu Gudang dan ke Label Barang. g. periksa Laporan stock dan phisik persediaan, 


\section{SARAN}

Selain perbaikan tersebut diatas saran dan tindakan nyata guna perbaikan managemen gudang secara menyeluruh adalah :

1. Membuat Struktur Organisasi dan job Diiscription petugas gudang secara jelas siapa yang bertanggung jawab

2. Membuat Standart Operasional Perushaan (SOP) Gudang, dan melakukan sosialisasi SOP gudang melalui pelatihan untuk meningkatkan kompetensi administrasi pergudangan termasuk akunting

3. Pimpinan sering turun langsung kelapangan untuk melakukan pengawasan, mendengarkan keluhan, permasalahn dan mencari alternative penyelesaiannya.sampai dengan petugas gudang dianggap mampu mandiri dan bertanggungjawab.

4. Menjadwalkan stock opname secara runtinitas dan berkelanjutan, misalnya Triwulan, semester, atau tahunan.

5. Sanski yang tegas dan kebijakan manjemen yang ketat dipergudangan baik administrasi, SDM ( missal : Dilarang mengambil barang tanpa BON yag sudah disetujui oleh pimpinan).

6. Perbaikan Perangkat Kerja Pergudangan (misalnya :aplikasi teknologi stock)

7. Perbaikan Sarana dan prasarana seperti : CCTV, penerangan, kunci / gembok, rak material, dan sebagainya

\section{DAFTAR PUSTAKA}

Catur Sasongko (2016), Akuntansi Suatu Pengantar. Salemba Empat, Jakarta.

Financial Accounting Standards Board (FASB) dalam Statement of Financial Concept (SFAC) No. 1 Handoko. (2015). Manajemen Sumber Daya Manusia, Cetakan Pertama. Bandung: Pustaka Setia, Bandung.

Ikatan Akuntansi Indonesia (IAI). 2018. Pernyataan Standar Akuntansi Keuangan (PSAK) No 1: Penyajian Laporan Keuangan . Jakarta: IAI

Kieso, D. E., Weygandt, J. J., \& Warfield, T. D. (2015). Intermediate Accounting:IFRS Edition (2nd ed.). New Jersey: John Wiley \& Sons, Inc.

Martono, Ricky. 2015. Manajemen Logostik Terintegrasi. Jakarta: PPM. hal. 343-344

Olivia Audrey Dkk (2019). Analisis Tata Letak Gudang Dengan Menggunakan Metode Dedicate Storage . Jurnal Asiimetrik: Jurnal Ilmiah Rekayasa\& Inovasi Volume 1.1, Januari 2019p-Issn 772655-186002 Universitaspancasila, Srengseng Sawah Jagakarsa, Jakarta 12640, Indonesia

Sheila Alifanny (2020). Analisis Sistem Akuntansi Persediaan Bahan Penolong Terhadap Pengendalian Internal CV Bumi Nusantara . e-Journal Ekonomi Bisnis dan Akuntansi, 2020, Volume VII (2) : 104-109 ISSN : 2355-4665 Jurusan Akuntansi, Fakultas Ekonomi dan Bisnis, Universitas Jember (UNEJ) Jln. Kalimantan 37, Jember 68121

Sumarsan, Thomas, 2017, Perpajakan Indonesia, Jakarta : Indeks.

Zaroni. 2017. Logistics \& Supply Chain Konsep Dasar Logistik Kontemporer Praktik. Jakarta: Prasetya Mulya Publishing. hal. 101 